\title{
The Legal Dimension of European Foreign Policy
}

\author{
Ramses A. Wessel \\ Professor of International and European Institutional Law, Centre for European Studies, \\ University of Twente, The Netherlands
}

Draft - To be published in Å.K. Aarstad, E. Drieskens, K.E. Jørgensen, K. Laatikainen and B. Tonra (Eds.), Handbook of European Foreign Policy, London: Sage, 2014 (forthcoming)

\section{Introduction}

European foreign policy is mostly studied from a political perspective. This is not surprising, given the fact that this policy area was not part of the original European Community treaty and was developed on the basis of political documents only. At the time of the creation of the European Union and its Common Foreign and Security Policy (CFSP) in the 1993 Maastricht Treaty, legal rules were laid down and started to form the framework for European foreign policy. Yet, the legal dimension of the European Union's foreign policy - characterized by questions on legal competences (who can or should do what) or the legal nature of CFSP decisions - was not clear to everyone (Wessel, 1999).

But also lawyers had difficulties in making sense of the legal nature of CFSP. Because of the uncommon roles of the key EU institutions (the Council, the Commission, the European Parliament and the Court) in CFSP, the different decision-making procedures (unanimity rather than qualified majority voting as the default voting rule) and the types of decisions (no regulations or directives), EU lawyers struggled with the acceptance of this policy as a research topic. Perhaps most importantly for many legal scholars was the absence of the two key notions of European law in CFSP: primacy (the idea that EU law should be given precedence over domestic law in cases of a conflict between the two) and direct effect (the idea that individuals and companies can invoke provisions in EU treaties and decisions in domestic court proceedings). Hardcore 'Community lawyers' would classify CFSP under 'international law', whereas international lawyers would still perceive it as European law (Koskenniemi, 1998).

While CFSP thus received relatively little attention in legal studies and textbooks, more recently EU external relations lawyers have adopted European foreign policy as an area of research (Van Vooren and Wessel, 2014), although the number of people specializing in the area remains limited and the debates seem largely detached from the ones in 
political science (an exception being Koutrakos, 2011b). One of the reasons to pay more attention to the legal dimension of CFSP was formed by the fact that over the years it had become clear that foreign policy was closely connected to other EU policy areas, such as the common commercial policy or development policy. The fact that CFSP formed a separate 'pillar' within the European Union did not deny its existence as part of the overall Union legal order, in which legal norms are interconnected and institutions combine CFSP and other policy areas in one agenda: CFSP was separate, but not separable form other external Union policies. A second reason was formed by the entry into force of the Lisbon Treaty in 2009, which resulted in a (modified) Treaty on European Union (TEU) on constitutional and institutional issues, and a Treaty on the Functioning of the European Union (TFEU) containing the various policy areas. Although CFSP is the only policy area that is regulated by the TEU and not by the TFEU, the EU's global ambitions are formulated more explicitly and at least an end was made to the division between the European Community and the European Union. These days, the EU as such is not only seen as the organization which enacts norms that influence its own member states, but also as the global actor for which a new institutional machinery (including a European External Action Service) has been developed. Finally, the coming of age of the EU's security and defence policy revealed a number of new legal questions (for instance on the EU's international responsibility), which triggered new research.

This chapter will zoom in on the legal research in the area of European foreign policy by using a thematic approach, rather than reviewing publications on a stand-alone basis. It will deal with the questions that over the years gained the most attention in legal research. The second section will first of all deal with research on the special legal nature of CFSP. The third section will focus on the assessment of the legal nature of the CFSP obligations. The fourth section will analyze views on the role of the Court of Justice of the European Union (CJEU) and the fifth section will address more recent research related to the role of the EU as a global actor. Conclusion will be drawn in the sixth section.

While the target audience of this handbook has been kept in mind, in terms of style and approach this chapter may stand out in contrast to other contributions to this book. Legal research differs from social science research both in terms of methodology and in the type of questions raised. While one may argue that most legal studies are driven by an 'empirical reality' in the sense that they simply aim to find the best possible interpretation of an existing legal situation, they do so by qualitative argumentation rather than by quantitative research. As legal texts form the main source for research, frequent references to treaty provisions, decisions and judgments form a tool that is commonly used in legal research. 


\section{The special legal nature of CFSP}

In the beginning, whenever European foreign policy received some attention by lawyers, it would relate to its distinctive nature in comparison to the 'supranational' European Community policies. These days, there exists a presumption in favour of legal uniformity, and the different, 'intergovernmental', nature of CFSP is less prominent (Sari, 2012; Wessel, 2009).

Indeed, for decades CFSP has been regarded as the 'odd one out' by most scholars (Hermann, 2008), although a minority has always placed emphasis on the unity of the Union's legal order (Von Bogdandy and Nettesheim, 1996; Wessel, 2003a, 2009). It emerged in an incremental, pragmatic fashion in the beginning of the 1970s when it became clear that a coordination of the different foreign policies of the member states was helpful, and occasionally even necessary, for the European Community to pursue its goals (Lak, 1989). These days the CFSP objectives are an integral part of the overall objectives of the European Union (see Article 3(5) TEU) and the policy area has developed from a purely intergovernmental form of cooperation in the days of the Eurooean Political Cooperation (EPC) in the 1970s and 80s to an area in which the member states have increasingly accepted new forms of institutionalization (Koutrakos, 2011a). While this 'legal uniformity' has now become more widely accepted, research over the years focussed largely on the differences between CFSP and the other Union policy areas and the need for coherence and consistency (Krenzler and Schneider, 1994; for an overview see also De Baere, 2008) and even 'post-Lisbon' as indicated by Article 24(1) TEU (Van Elsuwege, 2010). Indeed, despite the integration of the European Community into the European Union, in many aspects the nature of CFSP still differs from other 'common' policies, such as the Common Commercial Policy or the Common Agricultural Policy, and the differences have also been stressed 'post-Lisbon' (Koutrakos, 2008; Thym, 2009). It is a truism that over the years, member states have shown a willingness to cooperate, but remained reluctant to actually transfer competences (Cremona, 2006; Van Elsuwege, 2010; Sari, 2012). This makes it difficult to establish the scope of EU competence under CFSP. Also, while the institutions responsible for the CFSP do not differ from the ones in other policy areas, it is clear that any action on the part of the EU will, in the end, continue to depend on the consent of its member states.

In particular with the coming of age of this policy area, the 'constitutional' impact of CFSP decisions and actions became more clear (De Baere, 2008: Chapter 5; Wessel, 2005). While some hinted at an important role for national parliaments, in particular to uphold the democratic legitimacy and scrutiny of CFSP, the shift away from intergovernmentalism called for more extensive competence for the European Parliament as well (see Wagner, and Van Hecke and Wolfs in this volume). 


\section{Assessment of the legal nature of CFSP obligations}

\section{Procedural obligations}

Another recurring theme in the legal research on European foreign policy is the legal nature of the obligations. Given its 'political' nature and the absence of available legal procedures, the question of whether both the CFSP decision-making and its output belong to the legal research agenda continues to puzzle many lawyers. Yet, over the years, research has revealed the legal dimensions of CFSP in this area as well (Hillion and Wessel, 2008). The bottom line seems to be that CFSP is based on treaty obligations and that decision-making has to follow the rules laid down in the Treaty on European Union (TEU). CFSP provisions are phrased in quite mandatory terms, putting their perceived 'soft' nature into perspective, irrespective of the limited role the European Court of Justice is allowed to play.

Indeed, the systematic cooperation referred to in the list of CFSP means (Article 25 TEU) is to be established in accordance with clear procedural obligations (Article 32 TEU). This also implies that the member states are indeed obliged to inform and consult one another before they take foreign policy initiatives which would be 'of general interest' (Wessel, 1999). The content of the norm does not provide any other conditions than that the issue should be of general interest. There are no reasons to assume that the notion of consultation as used in Article 32 deviates from these general definitions, which has led to the conclusion that the EU member states are to refrain from making national positions on CFSP issues of general interest public before they have discussed these positions in the framework of the CFSP cooperation. Obviously, there is a difference between 'black letter law' and the 'law in practice', and the absence of legal means to actually monitor and enforce the rules has certainly influenced the (limited) research in this area. In many cases, European foreign policy decisions can only be 'enforced' by political means.

Over the years, the CFSP cooperation at all levels has become more intense, automatic and systematic. The 'European reflex' has become part of the decision-making culture in national ministries; traditional national reservations ('domaines réservés') have decreased in number as well as in intensity (Keukeleire and Delreux, 2014); and new issues have become part of the CFSP agenda (like terrorism). The flip-side, however, is that the larger member states, in particular, may tend to ignore the information and consultation procedures whenever sensitive policy issues are at stake. In cases like these, they take individual positions and diplomatic initiatives, or opt for cooperation in the framework of another international organization. This paradoxical situation reveals that CFSP has become part of the day-to-day policy-making in the national ministries as well as in Brussels, but that important or sensitive issues may also still being dealt with 
nationally or in other fora (Keukeleire and Delreux, 2014). Moreover, while in most other EU policy areas, the Commission may remind member states of their obligations through political as well as legal procedures, no such possibility exists in relation to CFSP.

\section{The binding nature of CFSP decisions}

From the outset, the binding nature of CFSP decisions has been less clear than in the case of other EU instruments, such as regulations and directives. The main reason would be the very limited role of the CJEU in relation to adopted CFSP decisions. Yet and apart from the indeed limited legal supervision - the obligatory force of CFSP decisions can clearly be derived from Article 28(2) TEU. Hence, CFSP decisions, once adopted, limit the freedom of member states in their individual policies. Member states are not allowed to adopt positions or otherwise to act contrary to the decisions. They have committed themselves to adapting their national policies to the agreed decisions. It is tempting to make comparisons with EU regulations, which also demand the unconditional obedience of member states once they are adopted. But, the Treaty text alone does not support reading the CFSP decisions along the same lines as the instruments used in Article 288 of the Treaty on the Functioning of the European Union (TFEU) - in particular where the addressees of the obligations or the direct applicability are concerned. A comparison with directives equally reveals glaring differences, for example regarding the implementation period of directives.

One strand of literature has constantly pointed to the nature of Article 29 decisions as concrete norms of conduct, demanding a certain unconditional behaviour from the member states. The committing nature of CFSP decisions is underlined by the strict ways in which exceptions are allowed (Gosalbo Bono, 2006; Hillion and Wessel, 2008). The arguments aim to reveal the limited possibilities agreed upon in the Treaty to deviate from adopted CFSP norms. Thus, Article 28(1) does not allow member states to simply invoke a change in circumstance to ignore a CFSP decision. This, together with the loyalty obligation (Article 24(3) TEU), has led some authors to conclude that the discretion offered to the member states to decide whether or not their implementation problems need to be brought to the attention of the Council, is limited. In case of any controversies concerning this issue, it seems to be up to the Council itself, to seek an appropriate solution. A similar reason has been followed in relation to the freedom of member states to conclude international agreements with third states. Following the loyalty obligation and the logic offered by the Court in cases on Community law, arguments have been presented that the member states' freedom in international dealings is restraint by adopted CFSP measures and international agreements concluded by the EU (Hillion and Wessel, 2008). 
It seems fair to say, however, that the majority view has difficulties in accepting a legally binding nature of CFSP norms, in the sense that they can actually limit a member state's freedom. This mainstream - though not fully accurate - view is, for instance, presented by Sari: 'The notion that the CFSP has a pre-emptive effect which renders the EU's competence exclusive as soon as it has exercised its powers under Title $\mathrm{V}$ of the TEU display a remarkable degree of ignorance about the evolution of the legal framework of European foreign policy cooperation; needless to say, this idea finds no support whatsoever either in law or practice' (Sari, 2012: 85).

\section{The Court of Justice and European foreign policy}

As we have seen, all EU institutions have a role to play in European foreign policy, albeit their role is subject to the specific procedures related to CFSP. Above we briefly addressed the roles of the Council, the Commission and the European Parliament. As far as two other institutions - the European Central Bank and the Court of Auditors - are concerned, the former's tasks are not related to CFSP, whereas the Court of Auditors' functions extend to all EU expenditure, so including finances spent on CFSP (Art. 287 TFEU). The present section will look into the role of the institution that can be seen as the driving force behind European integration, that is, the Court of Justice of the European Union (CJEU)* and its role in European foreign policy.

\section{The Court and internal policies}

Debates on the legal effects of CFSP norms are partly rooted in the fact that the powers of the Court of Justice are largely excluded by the treaty provisions. Most member states argued that foreign policy be shield from what some perceived to be 'judicial activism'; which resulted in a denial of the Courts competences in the area of CFSP (see Article 24(1) TEU and Article 275 TFEU). This is not to say that the CFSP provisions are not at all relevant for the European Court of Justice. The role of the Court in relation to CFSP has been subject to legal analysis (Brkan, 2012; De Baere and Koutrakos, 2012; Griller, 2013; Kronenberger, 2008; Hillion, 2014). As the Court is generally not allowed to judge on procedural or substantive CFSP obligations, its role is mainly limited to monitoring the use of competences by the decision-making organs. In that respect, the treaty provisions indicate a role for the Court in relation to Article 40 TEU. Conflicts on this issue can be brought before the Court, and the predecessor of Article 40 (Article 47) has indeed been used by the Court, albeit infrequently (Heliskoski, 2008; Hillion and Wessel, 2009; Van Vooren, 2009). The case law indicates that the Court of Justice is the ultimate arbiter to decide where the line of demarcation between the Union's issue areas lies. The reason for the relative broad interest in this topic lies in the fact that the choice for a legal basis (CFSP or another external competence) for a 
decision not only defines the role of the institutions in the decision-making procedure and the nature of the final decision, but also the extent to which member states can still act by themselves. After all, a legal basis in 'trade' would lead to an exclusive competence of the European Union, whereas a CFSP legal basis would lead to a more 'shared' exercise. Obviously, these legal battles have quite serious political implications: they are basically about the freedom of member states to define their foreign policies in a more intergovernmental setting in the Council, with the Commission claiming a more supranational role, because of links with other external policies which do fall within the Commission's sphere of competence.

Apart from Article 40 situations and general constitutional issues, such as the access to documents, research has pointed to additional situations in which the Court enjoys jurisdiction in relation to CFSP. The Court is competent to rule on proceedings, brought in accordance with the conditions laid down in the fourth paragraph of Article 263 TFEU, reviewing the legality of decisions providing for restrictive measures against a natural or legal person. This is the result of the proliferation of sanctions targeted at individuals in the (global) fight against terrorism. The implication is that, even if the restrictive measures are only laid down in CFSP measures, the Court has jurisdiction once the plaintiff is directly and individually concerned (see below). More in general, the integration of CFSP into the overall external relations regime of the EU has potentially broadened the scope of CFSP-related issues to be dealt with by the Court, and future cases may reveal a more active role of the Court in the area (Hillion, 2014).

Yet, it has also been pointed out that the current regime regarding legal protection reveals a number of shortcomings (De Wet, 2008; Eckes, 2009 d'Aspremont and Dopagne, 2008; Griller, 2008; Hinojosa Martinez, 2008; Van den Herik and Schrijver, 2008). The most obvious lack of judicial control is apparent when competences and decision-making procedures within the CFSP legal order are at stake. In that case, there are no possibilities for the Court to scrutinize either the decision-making procedures or the legal basis chosen for a CFSP decision. This means, for instance, that neither the Commission, nor the European Parliament can commence a procedure before the Court in cases where the Council has ignored their rights and competences in CFSP decisionmaking procedures in a situation where CFSP as a legal basis is not disputed. As far as the legal basis for decisions is concerned, there are no possibilities for the institutions or the member states to request the opinion of the Court. It is important to note that this brings about a situation in which the interpretation and implementation of the CFSP provisions (including the procedures to be followed) is left entirely to the Council (or perhaps worse: to individual member states). Keeping in mind their preference for 'intergovernmental' cooperation where CFSP is concerned, it may be understandable that member states at the time of the negotiations had the strong desire to prevent a body of 'CFSP law' coming into being by way of judicial activism on the part of the European Court of Justice, but it is less understandable that they were also reluctant to 
allow for judicial control of the procedural arrangements they explicitly agreed upon (although it is acknowledged that it may be difficult to unlink procedures and content).

\section{The Relationship with international law}

Externally, the role of the Court of Justice in relation to European foreign policy was mainly boosted on the basis of the cases brought by alleged terrorists on the UN and/or EU blacklist. In 2013 the Court released a final judgment in the most famous case, brought by Mr Kadi, who had been on the UN list for many years and as a result had been unable to access his financial assets. In the Kadi saga (but also in many other cases related to the fight against terrorism) the Court was challenged to reconcile UN Security Council obligations with the protection of fundamental rights, as part of the general principles of law to be ensured by the Court. In this case the Court held that the obligations imposed by an international agreement (in this case the UN Charter) could not have the effect of prejudicing the constitutional principles of the EU Treaty. While many lawyers pointed to a 'legal protection deficit' which thus became apparent (when both the EU Courts and the domestic Courts would not be able to review the UN measures, where could plaintiffs go?), others were more worried about the possibility suggested in the first judgment, where the (General) Court claimed to be competent to check the lawfulness of the resolutions of the Security Council. The very idea of a regional Court checking the validity of UN Security Council resolutions proved to be a source for heated academic debates (Palchetti, 2011). In that respect, the appeals judgment before the Court of Justice in the Kadi case (De Búrca, 2010; Eckes, 2009), essentially reversed several findings of the General Court. In 2013 the Court affirmed that it will continue to review EU listings implementing strict Security Council obligations in the face of lack of equivalent control at UN level. It insisted on a rather strict standard of review of such listings, and it undertook - for the first time substantive review of the reasons for listing offered by the EU. While this judgment certainly was a relief for those worrying about legal protection in the EU in the area of foreign policy and UN obligations, it will not make an end to the debate on how others will perceive the EU's position as to its claim to make its own assessment in the light of binding Security Council resolutions.

All in all, the anti-terrorism cases proved that judicial review cannot be seen as mere luxury when individual rights are at stake. While a full-fledged role of the Court in relation to CFSP (forcing member states to follow procedures or adhering to decisions) is not to be expected soon, the link between CFSP and other areas may continue to call upon the Court to take foreign policy developments into account when assessing the legality of the EU's external relations in other areas. 


\section{The legal dimension of the EU's global actorness}

The 2009 Lisbon Treaty strengthened the EU's ambitions as a world player. The EU has become a global political actor, but it can only act on the basis of existing legal competences and within the framework defined by international law. This section will assess the EU's international legal status as well as legal aspects of its representation in non-EU states and other international organizations.

\section{The European Union's international legal status}

When the 1957 Rome Treaty founded the European Economic Community (EEC), this new international organization was explicitly given competence to conduct international trade relations through its Common Commercial Policy, and to conclude international agreements through which it could associate itself with third countries. As the European integration progressed, the EEC, later European Community and now European Union, acquired powers in other areas such as environmental policy, energy policy, and indeed - foreign policy. At the time of the creation of the European Union (1992) and its Common Foreign and Security Policy, legal studies started analyzing the separate international legal personality of the EU. After all, CFSP did not form a part of the European Community (the international legal personality of which existed beyond any doubt), but of the EU (whose legal status was less clear) (Neuwahl, 1998). The debate on whether or not the EU was something that existed in legal distinction from its member states went on for over a decade (and occasionally comes up again). Where some would argue that the EU was merely an 'umbrella' covering collective actions of its member states (Pechstein, 1996), others pointed to the separate status the EU and the fact that it could conclude international agreements in its own name (Wessel, 2000, 2008).

The express provision on the EU's legal personality in the current treaty (Article 47) largely made an end to this discussion. Yet, as we have seen, this further highlighted the question of the division of competences between the EU and its member states in European foreign policy. This continues to form the core difficulty of EU external relations. Where political scientists would raise the question who represents the 'European interest' on the international scene (the EU or its member states, and how do these actions relate to each other; are they coherent, mutually supportive, or perhaps contradictory?), lawyers focus on legal competences (Van Vooren and Wessel, 2014). Who can do what and which rules need to be followed on the basis of treaty provisions, decisions or case law?

Indeed, given the EU's separate legal personality, from a legal perspective, it makes sense to continue to distinguish between the European Union as an international 
organization of which states can be members, and the (member) states themselves. In that sense the EU is clearly something different than a collection of 28 states. It has a distinct legal status, both in relation to its own members as well as towards third states. In legal terms, the European Union as an international actor then refers to the entity which has express legal personality and capacity to act in the international legal order. What is then characteristic of this international actor, and what makes some define it a sui generis international actor, is that the EU is neither a state with 'full international powers', nor is it a traditional international organization with limited powers to go against the will of its members (Eckes and Wessel, 2014). Yet, like any other international organization, the EU is based on the principle of conferred powers, that is, it can only act where its member states have given it the competence to do so. But, importantly, the member states may no longer be allowed to act once competences have been transferred and have been placed 'exclusively' in the hands of the Union. As a consequence, depending on the legal existence, scope and nature of the EU's external powers, the member states have, to a lesser or greater degree, a prominent role in the formation and execution of international action in the relevant area. Conversely, the role of the European Union (as the legal person) and its supranational institutions will then shift, depending on the policy area at issue. This is why it possesses significant legal competences and political clout which is distinct from that of its member states. This distinction was subject to extensive legal analysis over the years (Hillion and Koutrakos, 2010).

\section{External representation}

The creation of the post of High Representative (HR) in the Amsterdam Treaty and the post-Lisbon developments in relation to the establishment of the European External Action Service (EEAS; with its 'Union delegations' all over the world) triggered new research on the external representation of the European Union (Blockmans and Wessel, 2012). This research mainly focuses on the competences of the HR and the EEAS as well as, again, on the division of competences between the Union institutions and the member states in relation to external representation (see Pomorska and Juncos in this volume). Irrespective of the institutional changes, the question of 'who has a competence to do what' remains at the heart of what legal research is about.

Research thus assessed the new role of the HR, including the combination of the position of HR and her/his membership of the Commission (Article 17, paras 4 and 5 TEU). Given the focus, also in legal publications, on the need to increase the coherence in external relations, this combination was welcomed as one of the key innovations of the Lisbon Treaty (Kaddous, 2008; Paul, 2008; Whitman and Juncos, 2009). The potential impact of this combination on the role of the EU in international affairs lies in the fact that there could be a more natural attuning of different external policies, in particular where borders between policies are fuzzy, such as in crisis management. At 
the same time - as indicated above -, the continued separation between CFSP and other Union issues may very well lead to a need for different legal bases for decisions, and hence for the use of distinct CFSP and other Union instruments. This holds true not only for the outcome of the decision-making process, but also for the process itself, in which sincere cooperation between the Council and the Commission, supported by the HR and the new and hybrid EEAS (Blockmans, 2012; Blockmans and Laatsit, 2012; Van Vooren, 2011), will remain of crucial importance. The position of the High Representative has clearly been strengthened by the last treaty modification. The name change reflects the fact that it has become clear that the HR indeed represents the Union and not the (collective) member states. Even the President of the European Council exercises that position's external competences 'without prejudice to the powers of the High Representative of the Union for Foreign Affairs and Security Policy' (Article 15, para 6(d) TEU). All in all, the position of the HR has largely been assessed against the background of her possibility to bring an end to the unwanted separation between external policies. While one may argue that in a legal sense, everything is in place to ensure coherence in EU foreign policy, in the end it all comes down to the political will of member states to leave scope of manoeuvre for the HR and the EEAS (Helwig, 2013). EU foreign policy is an area where competences are, at best, shared between the EU and its member states and this demands a constant debate over how much the member states do entrust to the EU. In that sense the HR and the EEAS can only function as facilitators of coherence, without being able to guarantee the absence of diverging views or practice.

With the establishment of the EEAS in 2011, many experts in EU external relations law wrote on the nature of this special body, its competences and its potential role in streamlining EU foreign policy (see Hocking in this voume). Extensive studies also dealt with a detailed scrutiny of the legal texts themselves (Blockmans and Hillion, 2013; Wouters et al., 2013). As noted, special attention is devoted to the emerging diplomatic ambitions of the EU through the new Union delegations.

However, it has also been noted that member states seem to be somewhat anxious about the developments in this area, as illustrated by a special declaration to the Lisbon Treaty (No. 13). This declaration underlies the classic tension between, on one hand, the need to coordinate positions in international organizations and, where possible, have these presented by an EU representative and; on the other hand, the wish of many member states to maintain their own visible presence in international institutions. The transformation to 'embassy-like' delegations also proved to be difficult in the case of missions at international bodies such as the UN in New York or the Organization for Security and Co-operation in Europe in Vienna, since the Union still had to work out how to handle EU representation in multilateral forums. However, it is certainly the EU's ambition to 'progressively' expand these powers to other EU delegations as well (EEAS, 2011a, 2011b). Indeed, more in general, research indicated that the unified 
diplomatic presence for the EU in multilateral fora post-Lisbon has so far proven problematic (see Laatikainen in this volume).

\section{Common Security and Defence Policy}

The global ambitions of the EU are not limited to foreign policy, but include a clear security and defence dimension. In particular since the 'breakthrough' in the Treaty of Nice in 2003, the development of a Common Security and Defence policy (CSDP) and its civilian and military missions have been given extensive attention in legal research (Blockmans and Wessel, 2009; Koutrakos, 2013; Naert, 2010; Wessel, 2003b).

Legal research focused on a number of dimensions of CSDP (Koutrakos, 2013). Part of it relates to the development of the institutional framework (including the Political and Security Committee, the Military Committee, and the European Defence Agency). Some research also concentrates on the missions themselves, or on particular military or civilian missions and on the international agreements (SOFAs and SOMAs) underlying the missions. It will not come as a surprise, though, that legal research focused on an interpretation of the existing competences, rules and obligations in relation to these themes. Part of that analysis concentrates on the decision-making. As CSDP can be seen as forming part of CFSP, the decision-making takes place along similar lines.

This broad scope of CSDP led researchers to not only focus on 'security', but to investigate the 'defence' part as well. The conclusion is that the Treaty remains ambiguous on this point: 'The common security and defence policy shall include the progressive framing of a common Union defence policy. This will lead to a common defence, when the European Council, acting unanimously, so decides' (Article 42(2) TEU). Despite the careful wording of this provision in line with earlier versions, the Treaty does offer reasons to conclude that something has changed. First of all - and despite the claim that a 'common defence' is not yet included in CSDP - Article 42(7) TEU clearly reflects a collective defence obligation comparable to Article 5 of the NATO Treaty. What is different, however, is that NATO (as well as the Western European Union) started its life as a collective defence organization and only started to get engaged in other security operations later. The EU seems to follow the reverse path, by concentrating on external crisis management before establishing a mechanism to defend its own member states.

Extensive research also relates to the legal questions surrounding the actual CSDP missions (Blockmans, 2008; Koutrakos, 2013; Naert, 2010; Sari, 2012). Both military and civilian missions may be established on the basis of the CSDP provisions. On 1 January 2003, the EU launched the European Union Police Mission in Bosnia and Herzegovina (EUPM) as its first-ever civilian crisis management operation within the framework of the CSDP. On 31 March 2003, the EU deployed Operation Concordia, its 
inaugural military mission, to follow up on NATO's efforts to contribute to a stable and secure environment in the Former Yugoslav Republic of Macedonia. Since 2003, the EU has affirmed its operational capability through the launching of more than twenty CSDP operations, mainly in Africa and in the Western Balkans, but also in the EU's Eastern neighbourhood, the Middle East and Asia. The literature suggests that while most of the early operations were fairly successful, largely thanks to the fact that they were usually short-term and limited in both scope and size, they have also revealed shortfalls, bottlenecks as well as broader issues in crisis management. They range from 'growing pains', including the creation of the 'brand' of EU crisis management as well as the planning and drawing up of appropriate mandates for CSDP missions, to more enduring challenges such as coherence among EU policies, institutions and instruments, coordination with other international organizations, notably NATO and the UN, and consistency of 'output' (Naert, 2007).

In spite of the growing pains in the development of CSDP, the European Union has made significant strides in deploying crisis management operations. However, the issue of defining success of the CSDP is no longer measured in terms of merely launching missions, ensuring mission output and gathering operational experience. CSDP is past its age of innocence. Not only are greater intra- and inter-institutional coordination and cross-pillar coherence required by EU law and policy, the Union is also expected to conduct several operations at the same time, and to carry them out in line with both human rights law and international humanitarian law. In fact, the coming of age of CSDP made lawyers more aware of the fact that existing international law is applicable to many of these situations. Where the application of international diplomatic law was assessed in relation to the EEAS delegations discussed above, the international rules on humanitarian law, international responsibility and immunities in relation to CSDP formed a new research area (Evans and Koutrakos, 2013; Naert, 2010). The preliminary conclusions of this strand of research indicate that the Union, as a global (security) actor will have to abide by the existing international rules, despite the fact that most of these rules were created to regulate inter-state relations.

\section{Conclusion}

This chapter highlighted the main areas of legal research in the area of European foreign policy as well as some broad conclusions that were drawn on the basis of that research. Obviously it is impossible within the limited scope of this chapter to do justice to the many relevant insights that have been offered by colleagues in the field. Legal research on European foreign policy is relatively young. During the 1970s and 1980s, it was virtually non-existent, and it took until the beginning of the 1990s before the first pioneers entered this new terrain between European Community law and international law (references in Wessel, 1996). 
In the years that followed, research was mostly taken up by experts in EU external relations law. This explains the focus on the classic themes in that sub-discipline: the internal division of competences, both between the different EU policy areas (horizontal) and between the EU and its member states (vertical); the correct choice of legal basis (and its consequences in terms of institutional involvement and applicable procedures); a legal assessment of CFSP using Community law as a benchmark; the role of the Court of Justice (however limited, judgments do reassure lawyers in their own analysis); and finally the role of the EU as a global actor (including the relationship between CFSP and CSDP and international law).

All in all, research on the legal dimension of EU foreign policy has matured and has become an accepted field of study. Yet, because of the intergovernmental origin, the limited role of the Court of Justice and the exclusion of the 'legislative procedure' in the adoption of CFSP decisions, the scope of the legal dimension of EU foreign policy remains limited. The gaps in the research (such as on the legal impact of CFSP decisions in domestic legal orders or in relation to third states) are simply the result of choices made in the underlying treaties. When the 'empirical reality' - in terms of existing legal norms to study and analyze - forms the starting point, legal researchers are dependent on what politicians decided to regulate. At the same time, and given the 'political' nature of CFSP, it is striking that even in this area it has remained difficult to set up interdisciplinary research. While lawyers and political scientists occasionally cooperate in research projects, their research communities have so far largely remained separate. This means that research outcomes are usually not taken into account in other disciplines: only few political scientists are aware of the legal framework defining (and limiting) the development of EU foreign policy, and only few lawyers know the key theories underlying European integration or take the facts into account that are the result of (empirical) political studies.

With a view to new and upcoming research projects, we may conclude that more interand multidisciplinary research will be needed to fully grasp the complexities of EU foreign policy. The themes discussed in this chapter will continue to be present, but can only be further developed in a broader context. The developing international actorness of the EU will be a key research theme in the years to come, and the further developing 'state-like' functions of the EU will, in particular, raise new questions; not only in EU and international law, but also in international politics. 
* The abbreviation ECJ for the European Court of Justice is increasingly replaced by CJEU for Court of Justice of the European Union. While CJEU would refer to the 'main' Court in the EU's judicial system (settling legal disputes between EU governments and EU institutions; and under conditions dealing with claims from individuals, companies or organizations), it is also used more generally as to include the other two parts: the General Court (previously called the Court of First Instance, dealing with cases brought forward by private individuals, companies and some organizations, and cases relating to competition law) and the EU Civil Service Tribunal (ruling on disputes between the European Union and its staff).

\section{Bibliography}

Blockmans, S. (ed.) (2008) The European Union and Crisis Management: Policy and Legal Aspects. The Hague: T.M.C. Asser Press.

Blockmans, S. (2012) The European External Action Service One Year On: First Signs of Strengths and Weaknesses. The Hague: CLEER Working Paper Series 2012/2.

Blockmans, S. and Hillion, C. (eds) (2013) EEAS 2.0: A Legal Commentary on Council Decision 2010/427/EU Establishing the Organisation and Functioning of the European External Action Service. Brussels: CEPS / Stockholm: Sieps / Florence: EUI.

Blockmans, S. and Laatsit, M.-L. (2012) 'The European External Action Service: Enhancing coherence in EU external action?', in P.J. Cardwell (ed.), EU External Relations Law and Policy in the Post-Lisbon Era. pp. 135-59.

Blockmans, S. and Wessel, R.A. (2009) 'The European Union and crisis management: Will the Lisbon Treaty make the EU more effective?', Journal of Conflict and Security Law, 14(2): 265-308.

Blockmans, S. and Wessel, R.A. (eds) (2012) Principles and Practices of EU External Representation, The Hague: CLEER Working Paper series.

Brkan, M. (2012) 'The Role of the European Court of Justice in the field of Common Foreign and Security Policy after the Treaty of Lisbon: New challenges for the future', in P.J. Cardwell (ed.), EU External Relations Law and Policy in the Post-Lisbon Era. pp. 97-115.

Cremona, M. (2006) 'A constitutional basis for effective external action? An assessment of the provisions on EU external action in the Constitutional Treaty', EUI Working Paper, LAW No. 2006/30.

Curtin, D. and Eckes, C. (2008) 'The Kadi case: Mapping the boundaries between the executive and the judiciary in Europe', International Organizations Law Review, 5(2): 365-9.

d'Aspremont, J. and Dopagne, F. (2008) 'Kadi: The ECJ's reminder of the elementary divide between legal orders', International Organizations Law Review, 5(2): 371-9.

De Baere, G. (2008) Constitutional Principles of EU External Relations. Oxford: Oxford University Press. 
De Baere, G and Koutrakos, P. (2012) 'The interactions between the legislature and the judiciary in EU external relations', in P. Syrpis (ed.), The Judiciary, the Legislature and the EU Internal Market. Cambridge: Cambridge University Press. pp. 243-73.

De Búrca, G. (2010) 'The European Court of Justice and the international legal order after Kadi', Harvard International Law Journal, 51(1): 1-49.

De Wet, E. (2008) 'The role of European courts in reviewing conflicting obligations under international law’, International Organizations Law Review, 5(2): 359-64.

Eckes, C. (2009) EU Counter-Terrorist Policies and Fundamental Rights - The Case of Individual Sanctions. Oxford: Oxford University Press.

Eckes, C. and Wessel, R.A. (2014) 'The European Union from an international perspective: Sovereignty, statehood and special treatment', in T. Tridimas and R. Schütze (eds), The Oxford Principles of European Union Law - Volume 1: The European Union Legal Order, Oxford: Oxford University Press (forthcoming).

EEAS (2011a) EU diplomatic representation in third countries - second half of 2011. Council of the European Union, 11808/2/11 REV 2, Brussels, 25 November.

EEAS (2011b) EU diplomatic representation in third countries - first half of 2012. Council of the European Union, 18975/11, Brussels, 22 December.

Evans, M. and Koutrakos, P. (eds) (2013) International Responsibility: EU and International Perspectives. Oxford: Hart Publishing. pp. 339-58.

Gosalbo Bono, R. (2006) 'Some reflections of the CFSP legal order', Common Market Law Review, 43(2): 337-94.

Griller, S. (2008) 'International law, human rights and the EC's autonomous legal order', European Constitutional Law Review, 4(3): 528-53.

Griller, S. (2013) 'The Court of Justice and the Common Foreign and Security Policy', in A. Rosas, E. Levits and Y. Bot (eds), Court of Justice of the European Union - Cour de Justice de l'Union Européenne. The Court of Justice and the Construction of Europe: Analyses and Perspectives on Sixty Years of Case-law - La Cour de Justice et la Construction de l'Europe: Analyses et Perspectives de Soixante Ans de Jurisprudence. The Hague: T.M.C. Asser Press. pp. 675-92.

Heliskoski, J. (2008), 'Small arms and light weapons within the Union's pillar structure: An analysis of Article 47 of the EU Treaty', European Law Review, 33(6): 898-912.

Helwig, N. (2013) 'EU foreign policy and the High Representative's capability-expectations gap: A question of political will', European Foreign Affairs Review, 18(2): 235-54.

Herrmann, C.W. (2008) 'Much ado about Pluto? The "unity of the legal order of the European Union" revisited', in M. Cremona and B. de Witte (eds), EU Foreign Relations Law - Constitutional Fundamentals. Oxford: Hart Publishing. pp. 19-51. 
Hillion, C. (2014) 'A powerless court? The European Court of Justice and the Common Foreign and Security Policy', in M. Cremona and A. Thies (eds), The ECJ and External Relations: Constitutional Challenges. Oxford: Hart Publishing (forthcoming).

Hillion, C. and Koutrakos, P. (eds) (2010) Mixed Agreements Revisited. Oxford: Hart Publishing.

Hillion, C. and Wessel, R.A. (2008) 'Restraining external competences of EU member states under CFSP', in M. Cremona and B. De Witte (eds), EU Foreign Relations Law-Constitutional Fundamentals, Oxford: Hart Publishing. pp. 79-121

Hillion, C. and Wessel, R.A. (2009) 'Competence distribution in EU external relations after ECOWAS: Clarification or continued fuzziness?', Common Market Law Review, 46(2): 551-86.

Hinojosa Martinez, L.M. (2008) 'Bad law for good reasons: The contradictions of the Kadi judgment', International Organizations Law Review, 5(2): 339-57.

Kaddous, C. (2008) 'Role and position of the High Representative of the Union for Foreign Affairs and Security Policy under the Lisbon Treaty', in S. Griller and J. Ziller (eds), The Lisbon Treaty: Constitutionalism without a Constitutional Treaty? Vienna: Springer.

Keukeleire, S. and Delreux, T. (2014) The Foreign Policy of the European Union. 2nd ed. Basingstoke: Palgrave Macmillan.

Koskenniemi, M. (1998) 'International law aspects of the Common Foreign and Security Policy', in M. Koskenniemi (ed.), International Law Aspects of the European Union. The Hague: Kluwer Law International. pp. 27-44.

Koutrakos, P. (2008) 'Primary law and policy in EU external relations: Moving away from the Big Picture', European Law Review, 33(5): 666-86.

Koutrakos, P. (ed.) (2011a) The European Union's External Relations a Year after Lisbon. The Hague: CLEER Working Papers 2011/3.

Koutrakos, P. (ed.) (2011b) European Foreign Policy: Legal and Political Perspectives. Cheltenham: Edward Elgar.

Koutrakos, P. (2013) The EU Common Security and Defence Policy. Oxford: Oxford University Press.

Krenzler, H.G. and Schneider, H.C. (1994) 'Die Gemeinsame Aussen- und Sicherheitspolitik der Europäischen Union - Zur Frage der Kohärenz’, Europarecht, 29: 144-60.

Kronenberger, V. (2008) 'Coherence and consistency of the EU's action in international crisis management: The role of the European Court of Justice', in S. Blockmans (ed.), The European Union and Crisis Management: Policy and Legal Aspects, The Hague: T.M.C. Asser Press. pp. 199-211.

Lak, M.W.J. (1989) 'Interaction between European Political Cooperation and the European Community (external) - existing rules and challenges', Common Market Law Review, 26(2): 281-99. 
Naert, F. (2007) 'ESDP in practice: Increasingly varied and ambitious EU security and defence operations', in M. Trybus and N. White (eds), European Security Law. Oxford: Oxford University Press. pp. 61-101.

Naert, F. (2010) International Law Aspects of the EU's Security and Defence Policy, with a Particular Focus on the Law of Armed Conflict and Human Rights. Antwerpen: Intersentia.

Neuwahl, N.A.E.M. (1998) 'A partner with a troubled personality: EU treaty-making in matters of CFSP and JHA after Amsterdam', European Foreign Affairs Review, 3(2): 177-95.

Palchetti, P. (2011) 'Judicial review of the international validity of UN Security Council resolutions by the European Court of Justice', in E. Cannizzaro, P. Palchetti and R.A. Wessel (eds), International Law as Law of the European Union. Leiden, Boston: Martinus Nijhoff Publishers. pp. 379-94.

Paul, J. (2008) EU Foreign Policy after Lisbon: Will the New High Representative and the External Action Service Make a Difference? Munich: Centre for Applied Policy Research (CAP), Policy Analysis, No. 2.

Pechstein, M. (1996) 'Rechsstsübjektivität für die Europäische Union?’, Europarecht, 31(2): 137-44.

Sari, A. (2012) 'Between legalisation and organisational development: Explaining the evolution of EU competence in the field of foreign policy', in P.J. Cardwell (ed.), EU External Relations Law and Policy in the Post-Lisbon Era. The Hague: T.M.C. Asser Press. pp. 59-95.

Thym, D. (2009) 'Foreign affairs', in A. von Bogdandy, J. Bast (Eds), Principles of European Constitutional Law. 2nd ed. Oxford: Hart Publishing. pp. 309-43.

Van den Herik, L. and Schrijver, N. (2008) 'Eroding the primacy of the UN system of collective security: The judgment of the European Court of Justice in the cases of Kadi and Al Barakaat', International Organizations Law Review, 5(2): 329-38.

Van Elsuwege, P. (2010) 'EU external action after the collapse of the pillar structure: In search of a new balance between delimitation and consistency’, Common Market Law Review, 47(4): 987-1019.

Van Vooren, B. (2009) 'EU-EC external competences after the small arms judgment', European Foreign Affairs Review, 14(1): 7-24.

Van Vooren, B. (2011) 'A legal-institutional perspective on the European External Action Service', Common Market Law Review, 48(2): 475-502.

Van Vooren, B. and Wessel, R.A. (2014) EU External Relations Law: Text, Cases and Materials. Cambridge: Cambridge University Press.

Von Bogdandy, A. and Nettesheim, M. (1996) 'Ex Pluribus Unum: Fusion of the European Communities into the European Union', European Law Journal. 2(3): 267-89.

Wessel, R.A. (1996) 'Procedural priming of an EU Common Foreign and Security Policy', in J.H. de Wilde and H. Wiberg (eds), Organized Anarchy in Europe: The Role of States and Intergovernmental Organizations. London, New York: I.B. Tauris Publishers, pp. 267-80. 
Wessel, R.A. (1999), The European Union's Foreign and Security Policy: A Legal Institutional Perspective. The Hague: Kluwer Law International.

Wessel, R.A. (2000) 'Revisiting the international legal status of the EU', European Foreign Affairs Review, 5(4): 507-37.

Wessel, R.A. (2003a) 'The constitutional relationship between the European Union and the European Community: Consequences for the relationship with the member states', in J.J.H. Weiler and A. von Bogdandy (eds), Jean Monnet Working Papers (http://www.jeanmonnetprogram.org/archive/papers/03/030901-09.html).

Wessel, R.A. (2003b) 'The state of affairs in European Security and Defence Policy: The breakthrough in the Treaty of Nice', Journal of Conflict and Security Law, 8(2): 265-88.

Wessel, R.A. (2005) 'Good governance and EU Foreign, Security and Defence Policy', in D.M. Curtin and R.A. Wessel (eds), Good Governance and the European Union: Reflections on Concepts, Institutions and Substance. Antwerpen: Intersentia. pp. 215-51.

Wessel, R.A. (2008) 'The European Union as a party to international agreements: Shared competences, mixed responsibilities', in A. Dashwood and M. Maresceau (eds), Law and Practice of EU External Relations - Salient Features of a Changing Landscape. Cambridge: Cambridge University Press. pp. 14580 .

Wessel, R.A. (2009) 'The dynamics of the European Union legal order: An increasingly coherent framework of action and interpretation', European Constitutional Law Review, 5(1): 117-42.

Wessel, R.A. (2014) 'Common Foreign, Security and Defence Policy', in D. Patterson (ed.), WileyBlackwell Companion for European Union Law and International Law. Oxford/Malden: WileyBlackwell.

Wessel, R.A. and Van Vooren, R.A. (2013) 'The EEAS's diplomatic dreams and the reality of European and international law', Journal of European Public Policy, 20(9): 1350-67.

Whitman, R. and Juncos, A. (2009) 'The Lisbon Treaty and the Foreign, Security and Defence Policy', European Foreign Affairs Review, 14 (1): 25-46.

Wouters, J., De Baere, G., Van Vooren, B., Raube, K., Odermatt, J., Ramopoulos, T., Van den Sanden, T. and Tanghe, Y. (2013) The Organisation and Functioning of the European External Action Service: Achievements, Challenges and Opportunities. Brussels: European Parliament, Directorate-General for External Policies of the Union, Directorate B, Policy Department. 